\title{
Mode-coupling in photonic crystal fibers with multiple cores
}

\section{Kristensen, Martin}

Published in:

Lasers and Electro-Optics Europe

Link to article, DOI:

10.1109/CLEOE.2000.909688

Publication date:

2000

Document Version

Publisher's PDF, also known as Version of record

Link back to DTU Orbit

Citation (APA):

Kristensen, M. (2000). Mode-coupling in photonic crystal fibers with multiple cores. In Lasers and Electro-Optics Europe https://doi.org/10.1109/CLEOE.2000.909688

\section{General rights}

Copyright and moral rights for the publications made accessible in the public portal are retained by the authors and/or other copyright owners and it is a condition of accessing publications that users recognise and abide by the legal requirements associated with these rights.

- Users may download and print one copy of any publication from the public portal for the purpose of private study or research.

- You may not further distribute the material or use it for any profit-making activity or commercial gain

- You may freely distribute the URL identifying the publication in the public portal

If you believe that this document breaches copyright please contact us providing details, and we will remove access to the work immediately and investigate your claim 
Fabrication of photonic crystal structure in fluorine-doped silicon dioxide film by dry and wet etching processes

Kenji Kintaka, and Junji Nishii

Dept. Optical Materials, Osaka National Research Institute

1-8-31, Midorigaoka, Ikeda, Osaka 563-8577, Japas

Phone: $+81-727-51-9543, \quad$ Fax : $+81-727-51-9627$

Photonic crystals have been studied extensively because of their strong possibility in ligh control. Several techniques to form such structures have been reported so far. In this paper, we proposc novel method for fabrication of two-dimensional (sub-three-dimensional) periodic structures. We denonstrate the fabrication of a prow totype structure, i.e. two-dimensional array of mushroom structures.

Figure 1 shows the fabrication process. Pure $\mathrm{SiO}_{2} / \mathrm{F}$-doped $\mathrm{SiO}_{2}$ two-layer thin film was formed on Si substrate by plasma enhanced chemical vapor deposition (p-CVD) using chemical vapor deposition ( $\mathrm{P}$-CVD) using tetraethoxysilane (TEOS) and CF. The conin tnolar ratio. Then two-dimensionat periodic structure was formed by photolithography and dry etching with $\mathrm{CF}_{4}$. Finally, the mushroom structures were formed by the selective wet etching with 5\%-HF solution. Figure 2 shows the fabricatcd structurc. The period was $4.0 \mu \mathrm{m}$, and the thickness of the two layers were about $\mathrm{l} \mu \mathrm{m}$ ench. A mushroom structure was easily formed wocausc the etching rate of the $\mathrm{F}$-doped $\mathrm{SiO}_{2}$ film was six times as high as that of undoped film. Wic are continuing experimental work to form the sisucture with shorter period and to examine the optical properties of such structures. The shape of each component was controlled precisely depending on the concentration of fluorine. The structure stacking with the mushroom shapes or other shapes will be demonstrated in the presentation

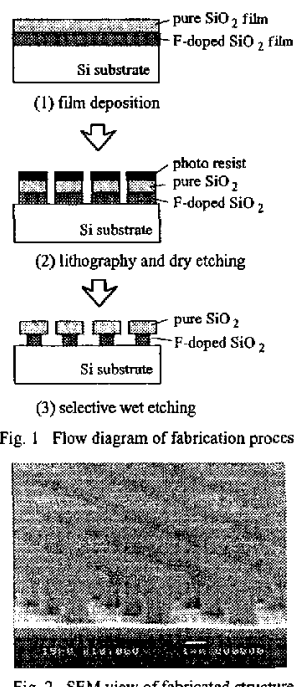

09.30 CME

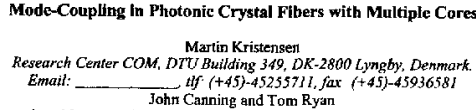

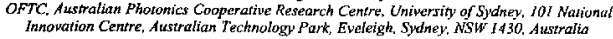

We have fabricated photonic crystal fiber (PCF) [1] with inuttiple cores by drawing a fiber preform from stacked glass tubes [2]. Fig. 1 is a cross-section of the fiber showing the three cores. One core is

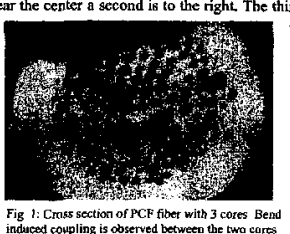

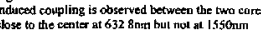

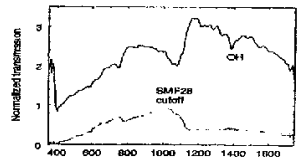

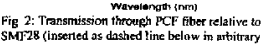

Tansmission is bigh through each core despite many unintentional defects in the cladding indiciting that the guidance is determined by the holes near to the core. The transmission spectrum through $1.5 \mathrm{gm}$ of the central core is shown in Fig. 2. The cutroff wavelength is aruend 400nm indicating an unusustlly

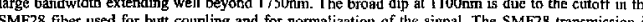
inserted as a dashed line. We find all PCF cores tilzation of the signal. The SMF 2 Gansmission is in Fig. 3. We observe no change in the mode-fiefd pattern when changing the in coupling or bending the fiber, conffirming the single--node behavior.
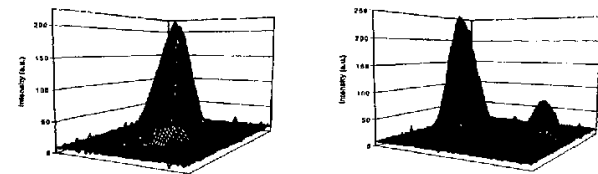

Hig 3: Central mode-feld pattem at $6328 \mathrm{8nm}$ without benting Fig 4: Hend-induced coupling 10 side core $16328 \mathrm{~nm}$ At $632.8 n m$ bending induces coupling between the fundamental modes of the two central cores as efficiency as a function of wavelength in sharp contrast to standard optical fibers and waveguides This may be explained by a tunneling effect throught the glass bndges connecting the core regions for long wavelengths the field is unable to penetrate through the narrow tigh-index bridges. When the wavelength gets comparable wo the size of the bridge coupling occurs. This sidantion restrables that of

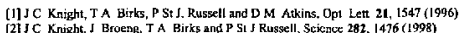

